\title{
Investigation of Virus Diseases and Molecular Detection of Little Cherry Virus 1 on Cherry Plants at Niğde Province
}

\author{
Qurat ul Ain Sajid ${ }^{1, a}$, Eminur Elçi ${ }^{1, b, *}$ \\ ${ }^{I}$ Department of Plant Production and Technologies, Faculty of Agricultural Sciences and Technologies, Niğde Ömer Halisdemir University, \\ 51200 Niğde, Turkey. \\ ${ }^{*}$ Corresponding author

\begin{tabular}{l|l} 
A R T I C L E I N F O & A B S T R A C T \\
\hline Research Article & $\begin{array}{l}\text { To investigate the virus infections of sour and sweet cherries, various locations of Niğde province } \\
\text { were examined during 2017. Ninety sweet and sour cherry leaf samples showing suspicious virus } \\
\text { symptoms were collected and screened with virus-specific primers: Little cherry virus 1 (LChV1), } \\
\text { Cherry necrotic rusty mottle virus (CNRMV), Prune dwarf virus (PDV), Prune necrotic ring spot } \\
\text { virus (PNRSV), Apple mosaic virus (ApMV), Cherry green ring mottle virus (CGRMV), Cherry } \\
\text { leaf roll virus (CLRV), Cherry mottle leaf virus (CMLV), Plum bark necrotic stem pitting associated } \\
\text { virus (PBNSPaV), Cherry twisted leaf virus (CTLV), Apple stem grooving virus (ASGV), Little } \\
\text { cherry virus 2 (LChV2), Cherry rusty leaf virus (CRLV), Apple stem pitting virus (ASPV), Apple } \\
\text { chlorotic leaf spot virus (ACLSV). Based on RT-PCR analysis, no amplification was observed } \\
\text { except LChV1 amplifications, dsRNA analysis resulted in one suspicious profile. To validate those } \\
\text { Accepted : 27/05/2019 } \\
\text { results, more sensitive TaqMan Real-Time PCR analysis and sequence analysis were conducted and } \\
\text { LChV1 was detected on 7 samples. It can be concluded that only a low quantity of LChV1 infections } \\
\text { was observed on some of the screened cherry samples. }\end{array}$ \\
$\begin{array}{l}\text { Keywords: } \\
\text { Cherry } \\
\text { dsRNA } \\
\text { RT-PCR } \\
\text { TaqMan Real-Time PCR }\end{array}$ &
\end{tabular} \\ TaqMan Real-Time PCR
}

Sequencing

\section{Introduction}

Cherry (Prunus avium L.) is the major stone fruit cultivated among other stone fruits like apple, pear, and apricot. It is mostly grown for its sour and juicy fruit. Cherry is the member of family Rosaceae and mainly cultivated in two type's sour cherry (Prunus cerasus L.) or sweet cherry (Prunus avium L.). Kemalpaşa (Izmir), Manisa, Akşehir, Ereğli, Hadim, Taşkent (Konya), Sultandağı (Afyon), Andırın (Kahramanmaraş), Ulukışla (Niğde) are the major cherry producing areas in Turkey. Niğde is producing 627,132 tons of cherries (TUIK, 2017).

Cherries are vulnerable to a number of diseases such as (pests and viral), which enhances the risk of valuable cherry yield. There are almost 30 viruses and viral diseases approximately available which can effect cherry production (Németh, 1986; Myrta and Savino, 2007). Moreover, diverse disease epidemics are general in cherry growing trees (Sabanadzovic et al., 2005; Isogai et al., 2004; Çevik et al., 2011; Bajet et al., 2008). Important viruses that infect cherries include: Prunus necrotic ring spot virus (PNRSV), Apple chlorotic leafspot virus (ACLSV), Apple mosaic virus (ApMV), Plum bark necrotic stem pitting associated virus (PBNSPaV), Cherry necrotic rusty mottle virus (CNRMV), Cherry green ring mottle virus (CGRMV), Cherry leaf roll virus (CLRV), Cherry rasp leaf virus (CRLV), Little cherry virus 1 (LChV1), Little cherry virus 2 (LChV2), Apple stem pitting virus (ASPV), Prune dwarf virus (PDV), Apple stem grooving virus (ASGV), Cherry mottle leaf virus (CMLV) and Cherry twisted leaf virus (CTLV) (Myrta et al., 2003; Bouani et al., 2004). All these viruses are spread all around the world and some of the viruses are reported in Turkey, except CNRMV, CMLV, CRLV, CTLV, ASPV, and ASGV in cherries. PDV was detected from sour and sweet cherries in Isparta region of Turkey (Öztürk and Çevik, 2015; Çevik et al., 2011), PBNSPaV was observed and first time recorded in Western Anatolia in Turkey (Gümüş et al., 2007), it is also observed in Eastern Anatolia on cherries and plums (Usta et al., 2007). This 
virus also has been spotted in the Malatya region of Turkey (Sipahioğlu et al., 2011). ACLSV and PNRSV incidences were confirmed on sweet and sour cherries in Isparta province of Turkey (Çevik et al., 2011). LChV1 was observed in cherries and detected for the first time in Osmaniye Turkey (Serçe et al., 2011). CGRMV was identified from cherries. Some of the viruses are transmitted by insect vectors as PNRSV by thrips, CLRV by nematodes and PNRSV, PDV is transmitted by pollens, while CLRV, PNRSV, and PDV are also transmitted by seeds and vegetative propagation (Wang et al., 2013). Vectors for CNRMV and CGRMV are still unknown (Martelli and Jelkmann, 1998), ApMV is transmitted by mechanical and vegetative propagation (Aramburu and Rovira, 2010), CTLV is transmitted by budding (Nemeth, 1986). These viral diseases cause a strong decrease in fruit size with mild fruit deformations. In most of the sensitive varieties, disease infection of a fruit tree often shows complete loss of yield. Some of the viruses are very dangerous economically as they affect the yield of cherry fruits by reducing the size of fruit and also fruit turned pale or some time colorless (Serçe et al., 2011). It can be easily transmitted by young trees, scions, woods. Moreover, the occurrence of these infections was dramatically reduced by using of different certification programs and by maintaining some cultural practices.

Virus-specific primers are the tools used in a polymerase chain reaction for specifically targeted the desired region and provide accurate genetic information about that specific region of our desired virus genome. It can also be easily used in genetic analysis. Many researchers have been used molecular technics for detecting the viral disease infection of cherries. While Niğde province has importance for cherry production, no any studies are available for the incidence of viruses in this province. Therefore, in this study investigation of some important virus diseases and incidence LChV1 was reported in Niğde province of Turkey. The study would be helpful for virus free cherry production.

\section{Materials and Methods}

\section{Plant Material}

Sweet cherry and sour cherry leaf samples showing suspicious virus symptoms were collected from different sites of Niğde province. Totally ninety (90) samples from three various locations, fifty-two (52) samples from Darboğaz village (Niğde), 15 from Niğde Ömer Halisdemir University campus (research area) and 23 from Niğde city center were collected June-July in 2017.

\section{Total RNA Extraction}

RNAs were extracted from leaves based on Guanidium Thiocyanate method (Chomczynski and Sacchi, 2006). To perform Guanidium Thiocyanate method, $1 \mathrm{ml}$ denaturation solution (250g Guanidium Thiocyanate, 293 $\mathrm{ml} \mathrm{dH}_{2} \mathrm{O}, 0.75 \mathrm{M}$ sodium citrate $17.6 \mathrm{ml}$, sarkosyl $10 \%$ $26.4 \mathrm{ml}$ ) was added to $0.1 \mathrm{~g}$ of fresh tissue and chopped on ice. The cell lysate was transferred to a $4 \mathrm{ml}$ polypropylene tube. $0.1 \mathrm{ml}$ of $2 \mathrm{M}$ sodium acetate was added in $1 \mathrm{ml}$ of lysate with $4.0 \mathrm{pH}$, mixed carefully; $1000 \mathrm{ml}$ watersaturated phenol, mixed carefully by inversion; $200 \mathrm{ml}$ of (49:1) chloroform/ isoamyl alcohol, shaked for $10 \mathrm{~s}$ by hand. Samples were cooled for $15 \mathrm{~min}$ on ice and centrifuged at $10.000 \mathrm{~g}$ on $4^{\circ} \mathrm{C}$ for $20 \mathrm{~min}$. The aqueous phase was transferred carefully by using a pipette, which contained mostly RNA to a new sterile tube. Isopropanol $(1000 \mathrm{ml})$ was added to the aqueous phase to precipitate RNA completely. All the samples were incubated at $-20^{\circ} \mathrm{C}$ for at least $1 \mathrm{~h}$. After centrifugation for $20 \mathrm{~min}$ at $10.000 \mathrm{~g}$ at $4{ }^{\circ} \mathrm{C}$ and the upper phase was discarded. The RNA pellet was dissolved in $300 \mathrm{ml}$ of denaturation solution and shifted to a new $1.5 \mathrm{ml}$ eppendorf tube. $0.3 \mathrm{ml}$ of isopropanol was added in the same tube. Samples were incubated again for at least $30 \mathrm{~min}$ at $-20^{\circ} \mathrm{C}$, and were centrifuged for about $10 \mathrm{~min}$ at $10,000 \mathrm{~g}$ for $4^{\circ} \mathrm{C}$. Later, the supernatant was discarded. RNA was re-suspended with $0.5-1 \mathrm{ml}$ of ethanol $75 \%$ and vortexed for a few seconds. Samples were incubated at room temperature for 10-15 min to mix the residues of guanidinium. Samples were centrifuged for $5 \mathrm{~min}$ at $10,000 \mathrm{~g}$ at $4{ }^{\circ} \mathrm{C}$ and supernatant was discarded again. RNA pellet air-dried at room temperature for 5-10 min. RNA had been dissolved in 100 $\mu 1$ of DEPC water or $0.5 \%$ SDS. The RNA pellet was incubated for $10-15 \mathrm{~min}$ at $60{ }^{\circ} \mathrm{C}$ to ensure complete solubilization. Yield and quality of RNAs were measured by spectrophotometer (Biospec-nano, Shimadzu, Japan). Total RNAs were stored in -20 for further analysis.

\section{cDNA Synthesis}

A two-step protocol was used for cDNA synthesis by using random hexamer primers according to instructions of

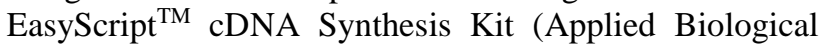
Materials Inc., Canada). In the first step for each $5 \mu$ l of RNA, $1 \mu$ of the random hexamer, dNTP $(1 \mu \mathrm{l})$ and $\mathrm{dH}_{2} \mathrm{O}$ $(7.5 \mu \mathrm{l})$ were used. For the second step, $5 \mathrm{x}$ RT buffer $(4 \mu \mathrm{l})$, RNase inhibitor $(0.5 \mu \mathrm{l})$, and RNase enzyme $(1 \mu \mathrm{l})$ were added. The steps were, Step 1: $65^{\circ} \mathrm{C} 5 \mathrm{~min} .,-20^{\circ} \mathrm{C} 1 \mathrm{~min}$., Step 2: $42^{\circ} \mathrm{C} 50 \mathrm{~min}$. and $85^{\circ} \mathrm{C} 5 \mathrm{~min}$.

\section{PCR Analysis}

PCR were comprised of sterilized water $(16.8 \mu \mathrm{l}), 10$ $\mu \mathrm{M}$ dNTP mix $(0.5 \mu \mathrm{l}), 25 \mathrm{mM} \mathrm{MgCl}_{2}(2 \mu \mathrm{l}), 10 \mathrm{x}$ Taq buffer $(2.5 \mu \mathrm{l}), 0.5 \mu \mathrm{l}$ of $10 \mu \mathrm{M}$ of each primer with $0.2 \mu \mathrm{l}$ of 5 Unit/ $\mu$ l Dream Taq DNA polymerase and $2 \mu \mathrm{l}$ of cDNA. Total final reaction mixture of PCR was $25 \mu \mathrm{l}$ reaction cycle consists of: denaturation $94^{\circ} \mathrm{C} 5 \mathrm{~min}, 40$ cycles of $94^{\circ} \mathrm{C}$ for $30 \mathrm{~s}, 55^{\circ} \mathrm{C}$ for $45 \mathrm{~s}$, and $72^{\circ} \mathrm{C}$ for $1 \mathrm{~min}$; and a final extension for $10 \mathrm{~min}$ at $72^{\circ} \mathrm{C}$. PCR products were imagined under UV light and run it with $1.5 \%$ agarose gel and stained with EtBr under a UV-trans illuminator BIO-RAD (Gel Doc). All the primers information used under this study is available in Table 1.

\section{Double-Stranded RNA (dsRNA) Extraction}

Double-stranded RNA extraction was performed by the following protocol; extraction buffer in a $15 \mathrm{ml}$ Falcon (STE 2x $1 \mathrm{ml}$, SDS 20\% $70 \mu \mathrm{l}$, Bentonite $20 \mu \mathrm{l}$, Phenol-TE $1.425 \mathrm{ml}$ ) was prepared with $0.750 \mathrm{~g}$ of samples. The samples with liquid nitrogen in precooled mortar and pestle were pulverized. Poured the powder to a $15 \mathrm{ml}$ falcon tube having extraction buffer with the spatula and funnel were transferred. After spinning aqueous phase to a new $1.5 \mathrm{ml}$ tube were transferred. Then the tasters were spinned to $10000 \mathrm{~g}$ at $20^{\circ} \mathrm{C}$ for $20 \mathrm{~min}$. Absolute alcohol volume to add $=0.176 \mathrm{x}$ phase aqueous volume was added. After 
washing the silica with $1 \mathrm{ml}$ STE $1 \mathrm{X}+15 \%$ alcohol supernatant was discarded and mixed well and the pellet was taken off with a tip. The cellulose CF11 was dried carefully with the help of the tip. The supernatant (about $400 \mu \mathrm{l})$ were retained. $3 \mathrm{M}$ sodium acetate $\mathrm{pH} 5.2(40 \mu \mathrm{l})$ was then added into the tubes. Isopropanol $(320 \mu 1)$ was further added into the same tubes. Samples were incubated overnight at $-20^{\circ} \mathrm{C}$ or $1 \mathrm{~h}$ at $-80^{\circ} \mathrm{C}$. Pellet was washed with $500 \mu 170 \%$ alcohol. The upper phase was removed and RNA pellet was dissolved in $10 \mu \mathrm{DEPC}$ water in the final stage.

TaqMan Real-Time PCR Analysis for the Universal Detection of LChVI

PCR reaction was done using each reaction $(20 \mu 1$ final volume) contained $2 \mu \mathrm{l}$ of cDNA, $2 \mathrm{x}$ TaqMan buffer (10 $\mu \mathrm{l}), 10 \mu \mathrm{m}$ each sense and antisense primer $(2 \mu \mathrm{l}), 10 \mu \mathrm{m}$
TaqMan probe $0.5 \mu \mathrm{l}$ and RNase free water $3.5 \mu \mathrm{l}$. The cycling conditions consisted of $45^{\circ} \mathrm{C}$ for about $30 \mathrm{~min}$, followed by $95^{\circ} \mathrm{C}$ for $15 \mathrm{~min} 35$ cycles in $3^{\text {rd }}$ step: $30 \mathrm{~s}$ at $95^{\circ} \mathrm{C}, 15 \mathrm{~s}$ at $55^{\circ} \mathrm{C}$ and $45 \mathrm{~s}$ at $60^{\circ} \mathrm{C}$. The TaqMan RealTime primers and TaqMan probe designed for this experiment are explained in Table 2.

\section{Sequencing and Phylogenetic Analysis}

Each virus-specific PCR outputs were directly sequenced from both sides. Sequencing was done using an AB1373 Automated Sequencer at MedSanTek Company (Istanbul, Turkey). The alignment search tool (BLAST) on the National Center for Biotechnology Information (NCBI) was used for sequence analyses. MEGA7 software was used to construct a phylogenetic analysis using the neighbor-joining method (Kumar et al., 2016).

Table 1 List of primers used in this study

\begin{tabular}{|c|c|c|c|c|}
\hline $\begin{array}{l}\text { Virus } \\
\text { Names }\end{array}$ & Primer Sequences $\left(5^{\prime}-3{ }^{\prime}\right)$ & $\begin{array}{l}\text { Coding } \\
\text { region }\end{array}$ & $\begin{array}{l}\text { Product } \\
\text { length }\end{array}$ & References \\
\hline ACLSV & $\begin{array}{l}\text { F: TTCATGGAAAGACAGGGGCAA } \\
\text { R: AAGTCTACAGGCTATTTATTATAAGTCTAA }\end{array}$ & $\mathrm{CP}$ & 677 bp & \\
\hline ASPV & $\begin{array}{l}\text { F: ATGTCTGGAACCTCATGCTGCAA } \\
\text { R: TTGGGATCAACTTTACTAAAAAGCATAA }\end{array}$ & $\mathrm{CP}$ & $370 \mathrm{bp}$ & \\
\hline ApMV & $\begin{array}{l}\text { F: ATCCGAGTGAACAGTCTATCCTCTAA } \\
\text { R: GTAACTCACTCGTTATCACGTACAA }\end{array}$ & MP & $262 \mathrm{bp}$ & Hassan et al., 2006 \\
\hline ASGV & $\begin{array}{l}\text { F: GCCACTTCTAGGCAGAACTCTTTGAA } \\
\text { R: AACCCCTTTTTGTCCTTCAGTACGA }\end{array}$ & $\mathrm{CP}$ & $273 \mathrm{bp}$ & \\
\hline PDV & $\begin{array}{l}\text { F: GTGTAGAAAGAAGAGAAGTCCGACAAG } \\
\text { R: ATCTAGAAGCAGCATTTCCAACTACGA }\end{array}$ & $\mathrm{CP}$ & 874 bp & Serçe et al., 2009 \\
\hline PNRSV & $\begin{array}{l}\text { F: GAACCTCCTTCCGATTTAG } \\
\text { R: GTCTCCCTAACGGGGCATCCAC }\end{array}$ & $\mathrm{CP}$ & 346 bp & $\begin{array}{l}\text { Sanchez-Navarro } \\
\text { et al., } 2005\end{array}$ \\
\hline CGRMV & $\begin{array}{l}\text { F: TAAACCCCTGCAATTCCACTC } \\
\text { R: CTCTAAGGAAACTGAAGGAAAA }\end{array}$ & $\mathrm{CP}$ & 192 bp & Zong et al., 2015 \\
\hline CNRMV & $\begin{array}{l}\text { F: TCCCACCTCAAGTCCTAGCAG } \\
\text { R: TGAACTTGGCCAGTTCTGCC }\end{array}$ & $\mathrm{CP}$ & 584 bp & Osman et al., 2017 \\
\hline CLRV & $\begin{array}{l}\text { F: GTTACTTTTACCTCCTCATTGTCCATGGTTG } \\
\text { R: GACTATCGTACGGTCTACAAGCGTGTGGCGTC }\end{array}$ & $\mathrm{CP}$ & $283 \mathrm{bp}$ & Kumari, 2009 \\
\hline CMLV & $\begin{array}{l}\text { F: GACTCTTCAGGGTTGGTTCG } \\
\text { R: CTCAATGTGATTTCGCAAGG }\end{array}$ & $\mathrm{CP}$ & $425 \mathrm{bp}$ & Zong et al., 2015 \\
\hline CTLV & $\begin{array}{l}\text { F: TCAGCAAGATTAAGGAGGTTG } \\
\text { R: ATNGGTTGAATTTGGCCAGT }\end{array}$ & $\mathrm{CP}$ & 562 bp & $\begin{array}{l}\text { Villamor et al., } \\
2013\end{array}$ \\
\hline CRLV & $\begin{array}{l}\text { F: GCTATGTGCGGGATAATGGAT } \\
\text { R: CACAAGCAAACTGATGAGCTCC }\end{array}$ & $\mathrm{CP}$ & $423 \mathrm{bp}$ & Osman et al., 2017 \\
\hline PBNSPaV & $\begin{array}{l}\text { F: TACCGAAGAGGGTTTGGATG } \\
\text { R: TAGTCCGCTGGTACGCTACA }\end{array}$ & $\mathrm{CP}$ & $270 \mathrm{bp}$ & $\begin{array}{l}\text { Sanchez-Navarro } \\
\text { et al., } 2005\end{array}$ \\
\hline LChV1 & $\begin{array}{l}\text { F: GGTTGTCCTCGGTTGATTAC } \\
\text { R: GGCTTGGTTCCATACATC TC }\end{array}$ & ORF & $300 \mathrm{bp}$ & Serçe et al., 2011 \\
\hline $\mathrm{LChV} 2$ & $\begin{array}{l}\text { F: CTCGGCGTATATGGTGGATGTTTA } \\
\text { R: CCGAATGCAGTGGGGATAGG }\end{array}$ & $\mathrm{CP}$ & $438 \mathrm{bp}$ & $\begin{array}{l}\text { Rott and } \\
\text { Jelkmann, } 2001\end{array}$ \\
\hline $\begin{array}{l}\text { nad5 } \\
\text { (internal } \\
\text { control) }\end{array}$ & $\begin{array}{l}\text { F: GATGCTTCTTGGGGCTTCTTGTT } \\
\text { R: TAGTCCGCTGGTACGCTACA }\end{array}$ & $\mathrm{CP}$ & $181 \mathrm{bp}$ & Hassan et al., 2006 \\
\hline
\end{tabular}

Table 2 PCR primer (Real-time) and probe (Katsiani et al., 2018) for LChV1 detection

\begin{tabular}{l|lcc}
\hline Primers/Probe & \multicolumn{1}{|c}{ Primer Sequences (5'-3') } & Position (bp) & Annealing Tm. $\left({ }^{\circ} \mathrm{C}\right)$ \\
\hline LChV1-F & CCAATGCACAAAGCACATATGA & $1.068-1.089$ & 62.6 \\
LChV1-R & ACCGCGACGTGGTCCTAATA & $1.184-1.203$ & 65.6 \\
LCh-P3 & FAM-TCGAARGGAGCTCTYCATGTTTCGCA-TAMRA & $1.156-1.181$ & $69-71$ \\
TaqMan Probe & & & 6 \\
\hline
\end{tabular}




\section{Results and Discussion}

In survey studies, ninety samples of sour and sweet cherries were individually collected and the most observed symptoms were leaf deformation, chlorosis, and mosaic patterns. Some of the sweet and sour cherries showed distinct symptoms-mosaic and ring spots and some showed no symptoms in the form of leaf curls (Figure 1). Similar infection symptoms have also been described by many investigators (Katsiani et al., 2015; Serçe et al., 2011; Zong et al., 2014) as affected trees had leaves showing pale yellow color, deformation and mosaic symptoms.

Scientists are focusing on fast, sensitive and reliable molecular methods that are essential to detect and eliminate severe virus diseases to improve the production quality of the desired crop. One of the most efficient and promising molecular technique is designing of virus-specific primers against particular viruses. However, this survey covers comparatively a limited area but no research has been found related to this area and it shows a comparatively good image of the healthy status of cherry fruits. All of the collected suspicious samples were screened by RT-PCR analysis for virus incidence and according to PCR analysis only 7 samples out of 90 found to be positive for LChV1 infection with the expected size $300 \mathrm{bp}$ (Figure 2). No, any amplification was observed as a result of CLRV, PBNSPaV, PNRSV, CTLV, CRLV, ApMV, ASGV, LChV2, CNRMV, ASPV, CMLV, ACLSV, PDV, and CGRMV screening. Among these viruses PDV, PNRSV, ACLSV, ApMV, PBNSPaV were reported in different regions of Turkey with the infection rate of $0.3-77 \%$ (Serçe and Ertunç, 2005; Usta et al., 2007) and 25-100\% in Mediterranean basin regions of Turkey (Myrta et al., 2003). PNRSV was detected in the East Mediterranean Region, Malatya, and Aegean Sea region of Turkey by Elisa and biological indexing (Azeri, 1994). ACLSV was reported in a different region of Yalova, Izmir, Malatya and East Mediterranean with the incidence of $23.2 \%$ and $45.1 \%$ (Dunez, 1986). LChD was initially detected in Osmaniye province of Turkey in a limited number (2 out of 7 samples) (Serçe et al., 2011). They reported about $89 \%$ similarities between two LChV1 isolates of the nucleotides of Prunus mahaleb L. in Osmaniye province of Turkey.

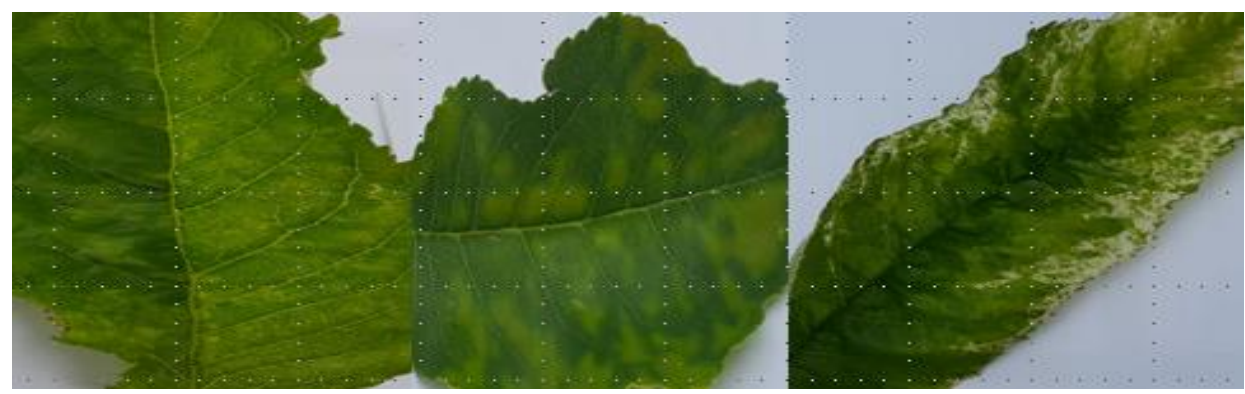

Figure 1 The most common observed virus symptoms as chlorosis and mosaic patterns on cherry leaves

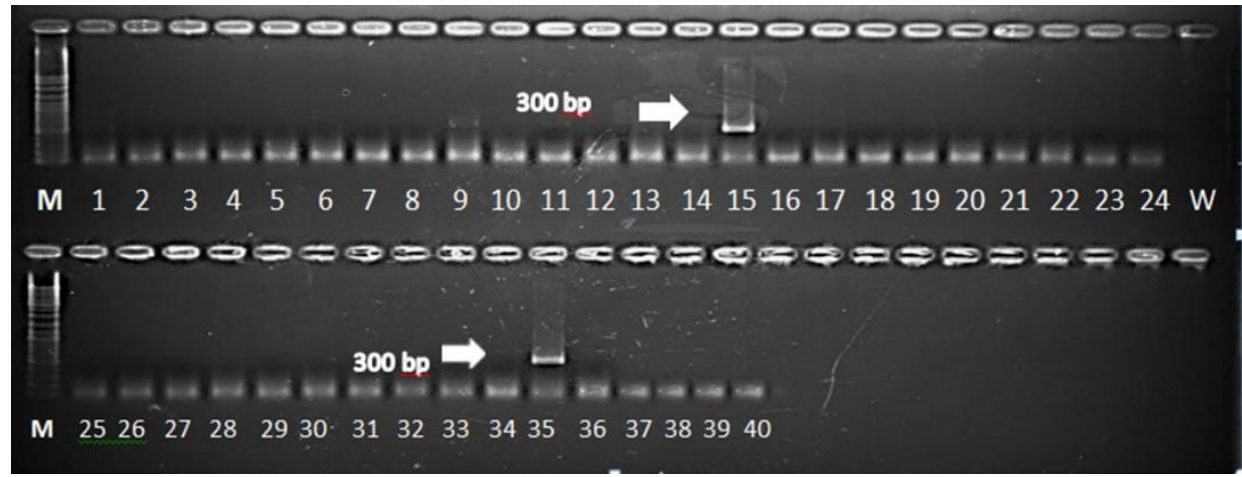

Figure 2 Agarose gel electrophoresis images of RT-PCR results for Little cherry virus 1 using virus specific primers (LChV1: Expected amplification size: 300 bp). M: 1 kb plus DNA Ladder (ThermoFisher Sci.), 1-40: Suspicious cherry samples, W: Water control

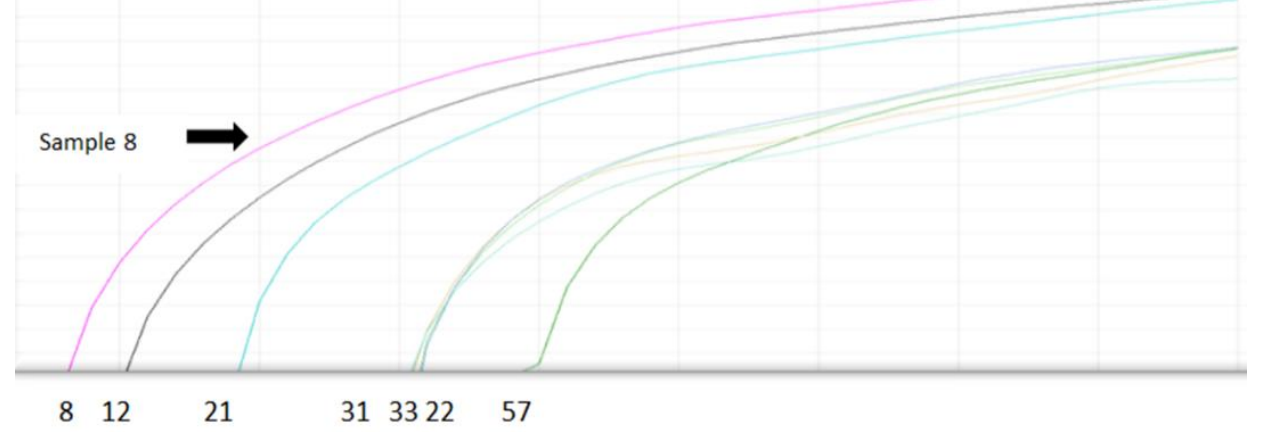

Figure 3 TaqMan real-time PCR analysis graph of cherry samples for Little cherry virus 1 screening. 8, 12, 21, 22, 31, 33, 57: RT-PCR positive cherry samples 


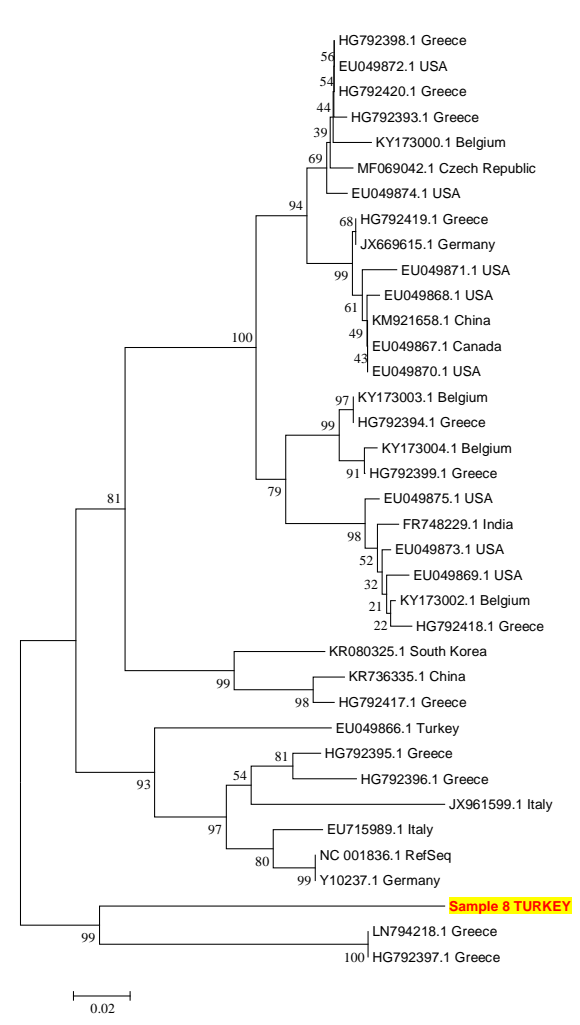

Figure 4 Phylogenetic analysis result of LChV1 isolate using neighbor-joining method with 1000 bootstrap value. Highlighted sample (Sample 8) belongs to this study and the remained isolates were obtained from GenBank

Moreover, no other viruses were detected in collected sweet and sour cherry samples. CNRMV, CMLV, CRLV, CTLV, ASPV, and ASGV are the viruses that had been screened for the first time on cherries in Turkey. Most of the cherry viruses screened in this research are transmitted by grafting, seeds, and pollen (Nemeth, 1986). All of the selected primer pairs were helpful for the detection of those virus infections before (Rott and Jelkmann, 2001; Rowhani et al., 1998; Sanchez-Navarro et al., 2005; Isogai et al., 2004; Varga and James, 2005; Kumari, 2009; Watpade et al., 2012). Along with virus-specific primer pairs, an internal control nad5 were also used to eliminate the risk of false result (Sharman et al., 2002). For the confirmation of LChV1 screening in sweet or sour cherry samples dsRNA analysis have done which revealed only one suspicious profile on an agarose gel. Even, seven out of ninety collected samples were found to be infected by low quantity of LChV1, which is linked with numerous plant disorders like Shirofugen stunt disease and Kwanzan stunting syndrome (Jelkmann and Keim-Konrad, 1997; Matic et al., 2009; Rott and Jelkmann, 2001; Candresse et al., 2013; Martelli et al., 2012), the quantity of virus could be the reason of this result. Due to the detection of one suspicious profile by dsRNA analysis, all of the suspicious LChV1 positive samples were screened using with more sensitive and advance universal TaqMan Real-Time PCR method to confirm that virus incidence. Based on the RealTime PCR analysis, amplification peaks were detected on 7 samples which confirm RT-PCR results (Figure 3).
Sequence analysis was used for double confirmation and one sample (no 8), which found to be positive for both RTPCR and Real-time PCR analysis, was selected and its amplicon was sequenced. According to BLAST analysis, the obtained sequence showed $84 \%$ of maximum similarity with GenBank LChV1 isolates. Phylogenetic analysis revealed two major groups as shown in Figure 4 and our isolate distinctly grouped in Greek isolates with high bootstrap value (\% 99). Since orchard holders in this area are slight responsive about how viruses infection spread and how their distribution can be controlled, the outcomes presented in this study will be beneficial to enhance our information on the newly growing plant viruses and permit the improvement of new advance approaches or techniques that avoids further spread of infections into new plants on large scales and establishing of virus free or clean standard programs in Niğde province of Turkey. Nevertheless, further surveys and epidemiological studies are needed to confirm virus infections.

\section{Acknowledgment}

The current research covers the partial Master's Thesis of Qurat-ul-Ain SAJID, which has been supported by BAP project no. GBT2017/02 BAGEP of Niğde Ömer Halisdemir University Niğde, Turkey.

\section{References}

Aramburu J, Rovira M. 2010. Incidence and natural spread of apple mosaic ilarvirus in hazel in north Eeast Spain. Plant Pathology, 49 (4): 423-427. Doi: 10.1046 / j.1365-3059. 2000. 00477.

Azeri T. 1994. Detection of virus diseases of stone fruits in Agean region of Turkiye. In: 9th Congress of Mediterranean Phyto pathological Union, Kuşadası Aydın, September. Türkiye, pp 511-513.

Bajet NB, Unruh TR, Druffel KL, Eastwell KC. 2008. Occurrence of two little cherry viruses in sweet cherry in Washington State. Plant Dis., 92 (2): 234-238. Doi: 10.1094/ PDIS-92-2-0234.

Bouani A, Rwahnih Al, Ghanem-Sabanadzovic M, Alami NA, Zemzami I, Myrta MA, Savino V. 2004. A preliminary account of the sanitary status of stone-fruit trees in Morocco. EPPO Bulletin, 34 (3): 399-402. Doi:10.1111/ j.13652338.2004.00760.

Candresse T, Marais A, Faure C, Gentit P. 2013. Association of Little cherry virus 1 (LChV1) with the Shirofugen stunt disease and characterization of the genome of a divergent LChV1 isolate. Phytopathology, 103 (3): 293-298. Doi: 10.1094 / Phyto-10-12 0275.

Chomczynski P, Sacchi N. 2006. The single-step method of RNA isolation by acid guanidinium Thiocyanate-phenolchloroform extraction: twenty-something years on. Nature protocols, 1 (2), 581. Doi:10.1038/nprot.2006.83

Çevik B, Yardimci N, Çulal-Kılı̧̧ H. 2011. Detection of viruses infecting stone fruits in Western Mediterranean region of Turkey. Journal of Plant Pathology, 27(1): 44-52. Doi: 10.5423/PPJ.2011.27.1.044.

Dunez J. 1986. Preliminary observations on virus and virus-like diseases of stone-fruit trees in the Mediterranean and Near East countries. FAO Plant Protection Bulletin, 34 (1): 43-48.

Gümüş M, Paylan IC, Matic S, Myrta A, Sipahioglu HM, Erkan S. 2007. Occurrence and distribution of stone fruit viruses and viroids in commercial plantings of Prunus species in western Anatolia, Turkey. Journal of Plant Pathology, 265-268. Doi: 10.jstor.org/stable/41998387. 
Hassan M, Myrta A, Polak J. 2006. Simultaneous detection and identification of four pome fruit viruses by one-tube pentaplex RT-PCR. J of Virol Methods., 133 (2): 124-129. Doi:10.1016/j.jviromet.2005.11.002.

Isogai M, Aoyagi J, Nakagawa M., Kubodera Y, Sato K, Katoh T, Inamori M, Yamashita K, Yoshikawa N. 2004. Molecular detection of five cherry viruses from sweet cherry trees in Japan. Phytopathological Society of Japan. 70 (5): 288-291. Doi:10.1111/j.14390434.1997.tb00357.

Jelkmann W, Keim-Konrad R. 1997.Immuno-capture polymerase chain reaction and plate-trapped ELISA for the detection of apple stem pitting virus. J. of Phytopathol., 145 (11-12): 499 503. Doi: 10.1111/ppa.12309.

Katsiani AT, Maliogka VI, Amoutzias GD, Efthimiou KE, Katis NI. 2015. Insights into the genetic diversity and evolution of Little cherry virus 1. Plant Pathol, 64 (4): 817-824. Doi: 10.1094/PDIS-01-17-0107.

Katsiani AT, Pappi P, Olmos A, Efthimiou KE, Maliogka VI, Katis NI. 2018. Development of a Real-Time RT-PCR for the Universal Detection of LChV1 and Study of the Seasonal Fluctuation of the Viral Titer in Sweet Cherry Cultivars. Plant Dis., 102 (1): 899-904.

Kumari S. 2009. Detection of Cherry leaf roll virus and Strawberry latent ring spot virus by one-step RTPCR. Plant Protect Sci., 45(4):140-143.

Kumar S, Stecher G, Tamura K. 2016. MEGA7: molecular evolutionary genetics analysis version 7.0 for bigger datasets. Mol Biol and Evol, 33 (7): 1870-1874. Doi: 10.1093/ molbev/msw054.

Martelli GP, Abou Ghanem-Sabanadzovic N, Agranovsky AA et al. 2012. Taxonomic revision of the family Closteroviridae with special reference to the grapevine leafroll-associated members of the genus Ampelovirus and the putative species unassigned to the family. Journal of Plant Pathology, 94: 7 19. Doi: 10.4454 .2012 .022 .

Martelli GP, Jelkmann W. 1998. Foveavirus, a new plant virus genus. Arch Virol., 143: 1245-1249. Doi: 10.1007 / s00 7050050372.

Matic S, Minafra A, Sanchez-Navarro JA, Pallas V, Myrta A, Martelli GP. 2009. Kwanzan stunting syndrome: detection and molecular characterization of an Italian isolate of Little cherry virus 1. Virus Res., 143 (1): 61-7. Doi:10.1016/ j.virusres.2009.03.005.

Myrta A, Savino V, 2007. Viruses and virus-like diseases of cherry in the Mediterranean. Acta Hortic., 795: 891-896.

Myrta A, Di Terlizzi B, Savino V, Martelli GP. 2003. Virus diseases affecting the Mediterranean stone fruit industry: a decade of surveys Virus and virus-like diseases of stone fruits, with particular reference to the Mediterranean region. Options Méditerran éennes: Série B. Etudes ET Recherches. 45: 15-23. Doi: php?IDPDF=3001761.

Németh M. 1986. Virus, Mycoplasma and Rickettsia Diseases of Fruit Trees. 1., Netherlands: Springer Netherlands. ISBN number 978-90-247-2868-8.

Osman F, Al Rwahnih M, Rowhani A. 2017. Real-time RT-qPCR detection of cherry rasp leaf virus, cherry green ring mottle virus, cherry necrotic rusty mottle virus, cherry virus a and apple chlorotic leaf spot virus in stone fruits. J of Plant Pathol., 99 (1): 279-285. Doi: 10.4454/jpp.v99i1.3789.

Öztürk Y, Çevik B. 2015. Genetic diversity in the coat protein genes of prune dwarf virus isolates from sweet cherry growing in turkey. The Plant Pathol J., 31 (1): 41. Doi:10.5423/PPJ.OA.07.2014.0063.

Rott ME, Jelkmann W. 2001. Characterization and detection of several filamentous viruses of cherry: adaptation of an alternative cloning method (DOP-PCR), and modification of an RNA extraction protocol. Eur J of Plant Pathol., 107(4):411-420. Doi: 10.1023/A:1011264400482.
Rowhani A, Maningas MA, Lile LS, Daubert S, Golino DA. 1998. Development of a detection system for viruses of of woody plants based on PCR analysis of immobilizedvirions. Phytopathology, 85: 347-352. Doi: 10. 1995 Articles / Phyto $85 n 03$ _ 347.

Sabanadzovic S, Ghanem-Sabanadzovic NA, Rowhani A, Grant JA, Uyemoto JK. 2005. Detection of Cherry virus A, Cherry necrotic rusty mottle virus and Little cherry virus 1 in California orchards. J of Plant Pathol., 173-177.

Sanchez-Navarro JA, Aparicio F, Herranz MC, Minafra A, Myrta, A, Pallas,V. 2005. Simultaneous detection and identification of eight stone fruit viruses by one-step RTPCR. Eur J of Plant Pathol., 111 (1): 77-84. Doi: 10.1007/s10658-004-1422.

Serçe ÇU, Ertunç F. 2005. Apple Chlorotic Leaf Spot Virus (ACLSV) status in Turkey and sensitive detection using advanced techniques. Turk J Agric and For., 29 (4): 251-257.

Serçe ÇU, Ertunç F, Öztürk A. 2009. Identification and genomic variability of Prune dwarf virus variants infecting stone fruit trees in Turkey. Journal of phytopathology, 157 (5), 298-305. Doi:10.1111/j.143904342008.01486.

Serçe ÇU, Gazel M, Çağlayan K. 2011. First report of Little cherry virus 1 in Turkey. Journal of Plant Pathology, 93 (4): 63-89.

Sharman M, Thomas JE, Dietzgen RG. 2002. Development of a multiplex immunocapture PCR with colourimetric detection for viruses of banana. Journal of Virol Methods., 89 (1-2): 75-88. Doi:10.1016/S0166-0934002044.

Sipahioglu HM, Usta M, Oksuz T. 2011. Partial characterization of a cherry isolate of a newly emerging stone fruit virus: Plum bark necrosis stem pitting associated virus. Arch of Phytopathol Plant Protect., 44 (10) : 1007-1013. Doi:10.1080 / 03235401003633857.

TUIK, 2017. Turkish Statistical Institute 2017. (http:/ /www.turkiye.gov.tr)

Usta M, Sipahioglu HM, Ocak M, Myrta A. 2007. Detection of Apricot latent virus and Plum bark necrosis stem pittingassociated virus by RT-PCR in Eastern Anatolia (Turkey). EPPO Bulletin 37 (1): 181-185. Doi:10.1111 /j.13652338.2007.01058.

Varga A, James D. 2005. Detection and differentiation of Plum pox virus using real-time multiplex PCR with SYBR Green and melting curve analysis: a rapid method for strain typing. J Virol Methods., 123 (2): 213-220. Doi:10.1016 /j.jviromet.2004.10.0 05 .

Villamor DEV, Ward KF, Collman SJ, Eastwell KC. 2013. First report of infection of cherry rusty mottle associated virus in Portuguese laurel (Prunus lusitanica) in Washington State. Plant Dis., 98 (5): 699-699. Doi: 10.1023/A:1008679224682.

Watpade S, Raigond B, Thakur PD, Handa A, Pramanick KK, Sharma, YP, Tomar M. 2012. Molecular detection of latent Apple chlorotic leaf spot virus in elite mother plants of apple. Indian J Virol., 23 (3): 359-363. Doi:10.1007/s13337-01201179 .

Wang X, Kohalmi, SE, Svircev A, Wang A, Sanfaçon H, Tian L. 2013. Silencing of the host factor eIF (iso) $4 \mathrm{E}$ gene confers plum pox virus resistance in plum. PLoS One, 8 (1), 50-627. Doi:10.1371/.pone.0050627.

Zong X, Wang W, Wei H, Wang J, Chen X, Xu L, Liu Q. 2014. A multiplex RT-PCR assay for simultaneous detection of four viruses from sweet cherry. Sci Hortic., 180: 118-122. Doi:10.1016/j.scienta.2014.10.017.

Zong X, Wang W, Wei, H, Wang J, Yan X, Hammond R W, Liu Q. 2015. Incidence of sweet cherry viruses in Shandong province, China and a case study on multiple infection with five viruses. Journal of plant pathology, (97) 1: 61-68. 